\title{
単層ラチスシェルの線形座屈荷重を上昇させるための 簡便な形状修正方法の検討 SHAPE MODIFICATION OF SINGLE-LAYER RETICULATED SHELLS FOR INCREASING LINEAR BUCKLING LOAD
}

\author{
山本 憲 司*
}

Kenji YAMAMOTO

\begin{abstract}
This paper proposed a technique of shape modification of single-layer reticulated shells for increasing linear buckling loads. The sensitivity analysis of the linear buckling load of a single-layer reticulated shell with respect to the nodal coordinates was performed, and the distributions of the sensitivity coefficients were examined. As a result, it was found that the distribution of the absolute value of $\mathrm{z}$ direction component of each buckling mode resembles the distribution of the sensitivity coefficients corresponding to the buckling mode. This tendency was utilized, and the technique of adding distribution of the absolute value of the buckling mode to a shell shape was proposed. The proposal technique was applied to several reticulated shells with various forms, and the efficiency was confirmed.
\end{abstract}

Keywords : single layer reticulated shell, linear buckling, shape optimization, sensitivity analysis, shape modification 単層ラチスシェル, 線形座屈, 形状最適化, 感度解析, 形状修正

\section{1. はじめに}

単層ラチスシェルの座屈荷重と曲面形状の関係は必ずしも十分明 らかになっていない。ライズが高いほど座屈荷重が大きくなるとい う傾向は良く知られているが、曲面の微妙な曲率の変化が座屈荷重 に及ぼす傾向などは分かっておらず、有限要素法などの構造解析に 頼らざるを得ない。座屈挙動は与えられた形状を解析する事で理解 されるが、その結果が構造形状にフィードバックされるのはライズ などの代表寸法に限られ、曲率分布が修正されることは少ない。

一方で、近年の建設技術、生産技術、構造解析技術の高度化に よって、以前は建設することの難しかった自由曲面ラチスシェルが 建設されるようになった。この為、自由曲面ラチスシェルの座屈や 耐力に関する研究の必要性が高まっている。座屈荷重は小さな不整 で大きく変化する場合が少なくない為、不整による大域的な力学性 状を十分に把握しないまま自由曲面を使用することは不測の事故を 起こしか数ない。外力分布の影響や、動的特性、材料非線形性など 様々な側面に対してその影響を詳細に把握し、施工実績の無い曲面 のかたちに対しては特に慎重に安全性を確認する必要がある。ま た、複雑な曲率分布を持つ自由曲面ラチスシェルは、特定のモード の座屈荷重が極端に小さくなり、不経済な構造物となる場合も考え られる。どのような曲面形状を採用するのが適切か、或いは、座屈
性状を改善するにはどのように形状を修正すべきかといった疑問に ついて考える必要がある。

こうした背景のもと、座屈荷重の大きな構造形状を求める方法と して、構造最適化手法を用いる方法が研究されている例え(活1 12)。また、 構造最適化手法を扱わないでも感度解析を行えば座屈荷重を上昇さ せる形状修正を把握することができる。しかし、一般的な構造解析 ソフトにそのような機能を持っているものは少ない。

もし、感度解析などの特別な計算を行わずに線形座屈解析の結果 から座屈荷重を上昇させるような形状修正を導く方法があれば、一 般の構造技術者にとって有用であると考える。既住の研究では、特 定の外力に対し剛性の高い形状を得るための方法として、能井、藤 井 ${ }^{13)}$ は変形に比例した形状修正を与える方法を、萩原 ${ }^{14)}$ は曲げモーメ ント分布に比例した形状修正を与える方法をそれぞれ提案してい る。しかし、座屈性状を改善する為の簡便な形状修正の方法を提案 している文献は、既往の研究には見当たらない。

文献15)では部分円筒殼にRS法を適用する為に、曲げの無い膜応力 状態を得ることを目的として分布外力により生じたたわみ形状を反 転させて形状に加えており、その過程で座屈荷重の上昇も確認され ている。また同様の耐力の上昇は文献16)等にも見られる。しかし、 他の最適化の文献5),10)では座屈荷重が大きい形状と曲げの無い形状が

\footnotetext{
$*$ 東海大学工学部建築学科 准教授・博士 $($ 工学)

Assoc. Prof., Dept. of Architecture, Tokai Univ., Dr. Eng.
} 
必ずしも一致しないことが報告されている。

本研究は、単層ラチスシェルの線形座屈解析と感度解析を行い、 感度係数の分布の傾向を調查する。そしてその調查結果から、感度 解析を行わずに座屈モードのみから簡便に線形座屈荷重を上昇させ るような形状修正の分布を生成する方法を提案する。

\section{2. 線形座屈荷重の感度解析}

\section{1 感度解析の方法}

線形座屈荷重係数の感度係数について示す。構造物の線形座屈荷重 係数は一般に次式のような一般固有值問題を解くことで求められる。

$$
\left[\mathbf{K}_{L}+\lambda_{i}^{C} \mathbf{K}_{G}\right] \phi_{i}=\mathbf{0}
$$

ここに、 $\mathbf{K}_{L}$ は線形岡性マトリクス、 $\mathbf{K}_{G}$ は幾何岡性マトリクス、 $\lambda_{i}^{C}$ は線形座屈荷重係数、 $\phi_{i}$ は線形座屈モードを表す。

上式の両辺を設計変数 $x_{j}$ で偏微分すると、次式となる。

$$
\left[\mathbf{K}_{L}+\lambda_{i}^{C} \mathbf{K}_{G}\right] \frac{\partial \boldsymbol{\phi}_{i}}{\partial x_{j}}+\left[\frac{\partial \mathbf{K}_{L}}{\partial x_{j}}+\lambda_{i}^{C} \frac{\partial \mathbf{K}_{G}}{\partial x_{j}}\right] \phi_{i}+\frac{\partial \lambda_{i}^{C}}{\partial x_{j}} \mathbf{K}_{G} \phi_{i}=\mathbf{0}
$$

両辺の左から $\phi_{i}^{T}$ を乗じると、(1)式と $\mathbf{K}_{L} 、 \mathbf{K}_{G}$ の対称性から、左辺第 1 項は 0 となるので、次のような線形座屈荷重係数の感度係数を得る。

$$
\frac{\partial \lambda_{i}^{C}}{\partial x_{j}}=-\frac{\phi_{i}^{T}\left[\frac{\partial \mathbf{K}_{L}}{\partial x_{j}}+\lambda_{i}^{C} \frac{\partial \mathbf{K}_{G}}{\partial x_{j}}\right] \phi_{i}}{\phi_{i}^{T} \mathbf{K}_{G} \phi_{i}}
$$

本研究では上式に従って節点のz座標に関する線形座屈荷重係数の 感度係数を算出する。(3)式の $\mathbf{K}_{G}$ には応力を含んでいるため、応力 の感度係数が必要になる。この感度係数の值は、別途直接微分法に よる感度解析により求める。

\section{2 感度解析の数值解析例}

ラチスシェルの節点座標に関寸る線形座屈荷重の感度解析を行 い、感度係数の分布の傾向について調查する。

解析モデルを図 1 に示す。スパン $40 \mathrm{~m} 、$ ライズ $8 \mathrm{~m}$ のEP曲面で表され る二方向格子シェルである。曲面の形状は次式で与えられる。

$$
z=-\frac{1}{100}\left(x^{2}+y^{2}\right)+8 \quad \text { (unit:m) }
$$

外力は等分布荷重 $1.0 \mathrm{kN} / \mathrm{m} 2$ とし、各節点に支配面積に応じて節 点集中荷重として与える。部材は $267.4 \times 6.0$ とし、ヤング係数 $206 \mathrm{GPa}$ 、せん断弾性係数 $79.2 \mathrm{GPa}$ 、接合部は剛接合である。支持 条件は周辺ピン支持として解析を行った。

二方向格子シェルの1次から4次までの線形座屈モードを図2(a)に示 す。図中に示した $\lambda_{1}^{C}=5.068$ といった值は線形座屈荷重係数を表して いる。2次モードと3次モードの座屈荷重は等しく、z軸周りに90度回 転させると2次モードと3次モードは互いに同じモード形状をしてい る。次に各節点の Z座標に対する線形座屈荷重係数の感度係数の值を モデル上のz方向にとり、それらを直線で結んでモード状に表現したも のを図2(b)に示す。図中にmax として記入した值は、感度係数の最大 值である。図2(a)と図2(b)を比較すると、1次の座屈モードはx、y方向 共に1波のモードであるのに対し、感度係数の分布はx、y方向に1.5波 の分布になっている。2次の座屈モードはx方向に1波、y方向に 1.5 波 であるのに対して、感度倸数の分布はx方向に 1.5 波、y方向に2.5波になっ ている。3次、4次モードも同様の傾向が確認できる。感度係数の分布 は座屈モードより半波もしくは1波多く波打つ分布となるようである。

次に図2(a)に示した座屈モードのz方向成分に対して絶対值をとった 図（下方向に凸のモード形を上方向凸に反転させた図）を図2(c)に示 す（ただしモードのx,y方向成分は0としている）。この図の分布はい
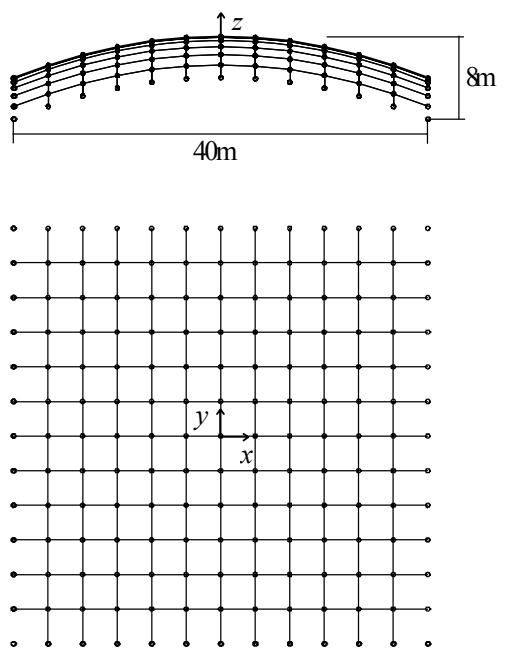

図1 解析モデル

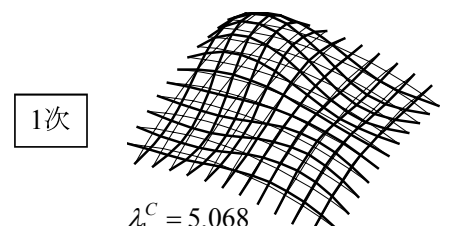

$\lambda_{1}^{C}=5.068$
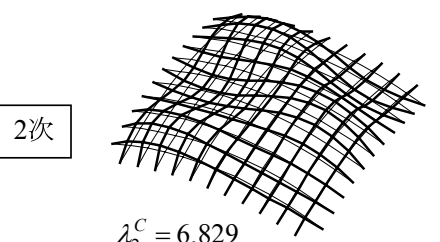

3次

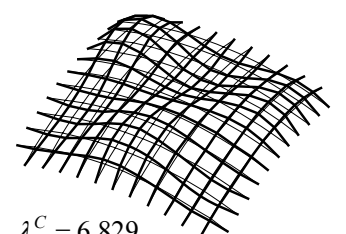

$\lambda_{3}^{C}=6.829$

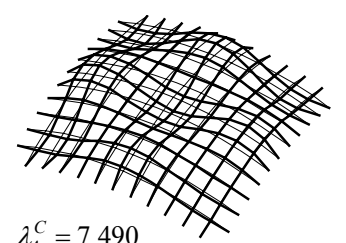

(a) 座屈モード

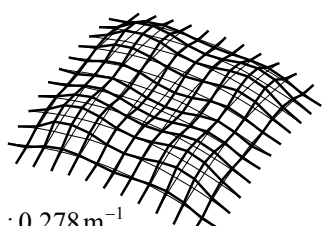

$\max : 0.278 \mathrm{~m}^{-1}$
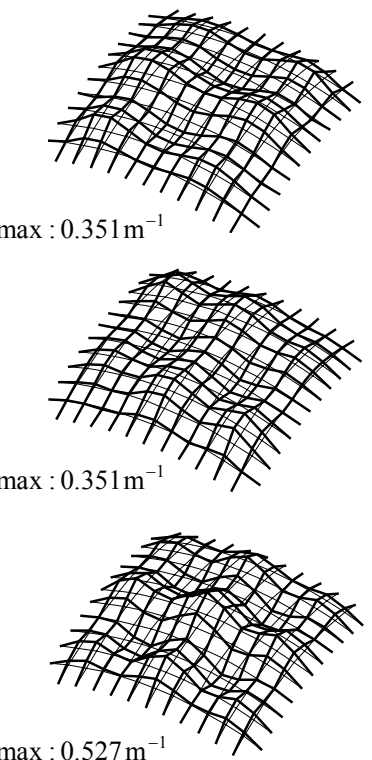

(b) 感度係数分布
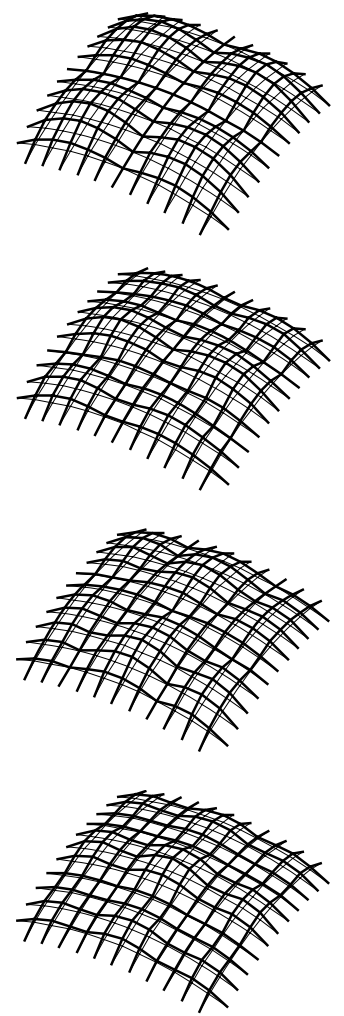

（c）座屈モードの絶対値

図2 座屈モードと感度係数の分布の比較 
ずれのモード次数の場合も感度係数の分布（図2(b)）と良く似ている ことが分かる。次章以降ではこの傾向を利用して単層ラチスシェル の形状修正を行い、座屈荷重を上昇させることを試みる。

\section{3. 線形座屈荷重を上昇させる簡便な形状修正方法}

前章では座屈モードのz方向成分の絶対值の分布(図2(c))が座屈荷重 の感度係数の分布(図2(b))に良く似ていることを示した。感度係数の分 布はその関数を効率よく増加させる方向となり、この分布に比例し た修正を行う方法は最適化の分野では最急降下法と呼ばれている。 従って、感度係数の分布と良く似た座屈モードの絶対值の分布をラ チスシェルのz座標に足し合わせることで、座屈荷重を上昇させるこ とが期待できる。

ただし、この形状修正はすべての節点が上向きに移動することに なるので、座屈荷重が上昇した理由は単にライズが上昇したためで あるかもしれない。この為、形状修正前後で条件が等しくなるよ う、構造材の総体積が形状修正前と同一となるよう高さ方向に節点 べて部材断面を一様としており、この為、構造材総体積を一定にす る条件は、部材長総和を一定とする条件として扱う。この条件は簡 単な反復計算により考慮した。具体的な形状修正の手順を以下に記す。

Step1 初期の部材長総和 $L_{0}$ を算定する。

Step2 座屈荷重を上昇させようとする座屈モードのz方向成分の絶 対值を節点 $z$ 座標に $\alpha$ 倍して加える。 $z_{i}=z_{i}+\alpha\left|\phi_{j i}\right|$

Step3 形状修正後の部材長総和 $L$ を算定する。

Step4 $L \approx L_{0}$ の時は終了、それ以外の時 $z_{i}=z_{i} \times \frac{L_{0}}{L}$ として、z座 標を更新LStep3に戻る。

上の手順ではNewton法などの非線形解法を適用しておらず簡易な扱 いではあるが、本報で扱ったモデルではいずれも数十回程度の繰 り返し計算で $L_{0}$ に収束した。

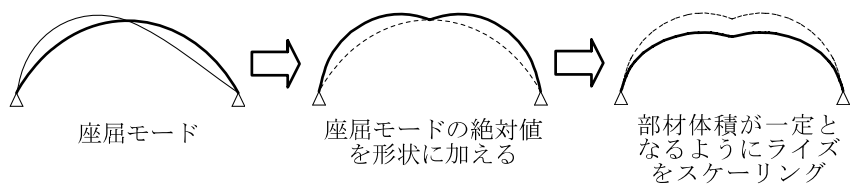

図3形状修正の手順

\section{4. 形状修正の数值解析例}

3 章で述べた形状修正の方法を幾つかの解析モデルに適用し、座屈 荷重が実際に上昇するかどうか調查を行う。

\section{1 二方向格子シェル}

解析モデルはスパン $40 \mathrm{~m} 、$ ライズ $8 \mathrm{~m}$ の二方向格子シェルとし、EP 曲面で表されるモデル(図4(a))(以下、格子シェルAと呼ぶ)と支持節点 が同一平面上にあるモデル(図4(b))(以下、格子シェルBと呼ぶ)の二つ のモデルについてそれぞれ解析を行う。格子シェルAは2章で示した モデルと同じものである。格子シェルA， B ともに曲面はx-y平面上で 等間隔となるように12分割している。格子シェルBの節点座標は(5)式 で与えた。

$$
z=\frac{1}{20000}\left(x^{2}-20^{2}\right)\left(y^{2}-20^{2}\right)
$$

(unit:m) 座標のスケーリングを行うことにした(図3)。本報で扱うモデルは寸

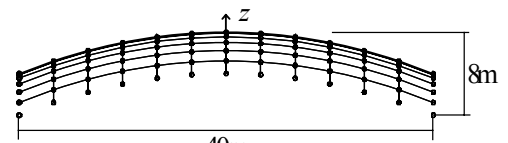

(a) 格子シェルA

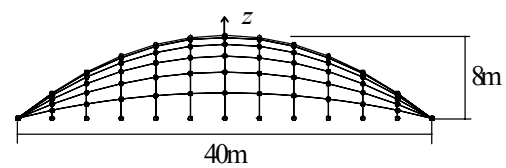

(b) 格子シェルB

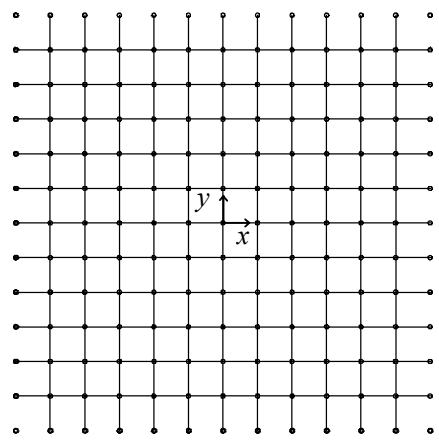

（c）格子平面図

図4 解析モデル (二方向格子シェル)

$\times 6.0$ とし、ヤング係数 $206 \mathrm{GPa}$ 、せん断弾性係数 $79.2 \mathrm{GPa}$ 、接合部は剛 接合である。支持条件は周辺ピン支持として解析を行った。

格子シェルAに対して、提案手法により1次の座屈モードについて 形状修正を行い、座屈荷重の変化を調查する。形状修正として加え る座屈モードの絶対值の最大振幅を、 $0 \mathrm{~m} \sim 0.5 \mathrm{~m}$ の範囲で連続的に変 化させて線形座屈解析を行った。結果を図5(a)に示す。図の横軸は形 状修正量であり、形状修正前後における形状のz座標の差の最大值を

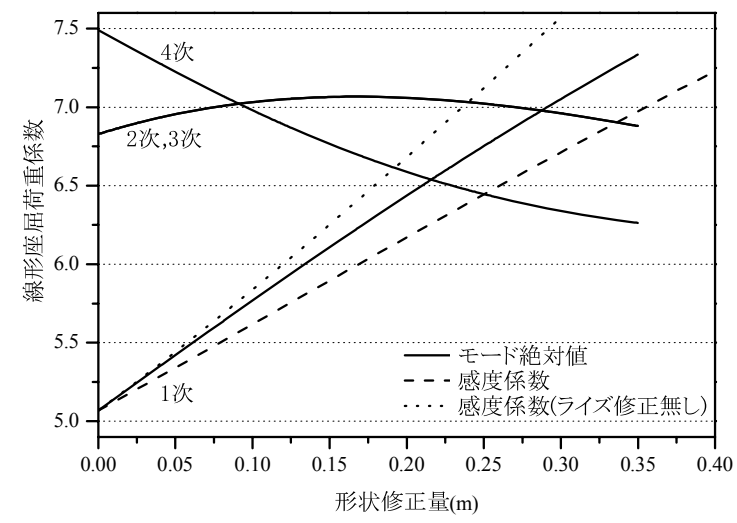

（a）線形座屈荷重係数と形状修正量の関係

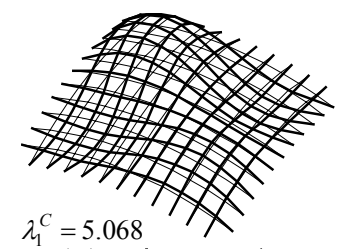

(b) 座屈モード

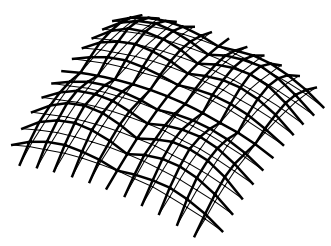

（c）座屈モードの絶対値

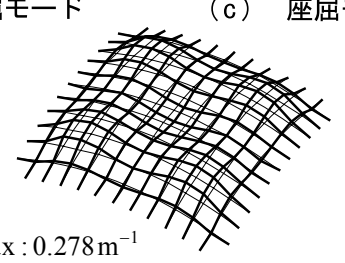

(d) 感度係数分布

図5格子シェルAの 1 次モードに対する形状修正 
表す。この值は構造材総体積を一定とするライズのスケーリングを 行っている為、加えたモードの最大振幅 $(0 \mathrm{~m} \sim 0.5 \mathrm{~m})$ とは異なる值 となる。縦軸は線形座屈荷重を表す。図中の実線の曲線が 1 次から 4 次までの座屈荷重の変化を表しており、対応するモード次数は図中 に記入してある。形状修正後にモードや座屈荷重は変化し、それら の並びに入れ替わりを生じるが、本論文では形状修正量を少しずつ 変化させることで、例えば初期形状の1次モードから連続的に変化し たモードを形状修正後においても1次モードと呼んでいる。

また、1 次の座屈モード及び1次の座屈モードの絶対值の分布を図 5(b),(c)に、1次座屈荷重係数の節点z座標に対する感度係数の分布を図 5(d)に示す。なお、これらの図は図2で既に一度示している。

図5(a)を見ると形状修正量が $0.35 \mathrm{~m}$ の時、1次の線形座屈荷重係数は 5.07から7.33へと5割ほど上昇した。座屈モードの絶対值の分布に比例 した形状修正を与えることによって、座屈荷重が上昇していること がわかる。ただし、1次モードの座屈荷重が上昇するに従い、4次 モードの座屈荷重が低下しており、形状修正量 $0.2 \mathrm{~m}$ 付近で最小座屈 荷重の入れ替わりが生じている。また、同図中には座屈荷重の改善 効率を見る為に、形状修正に感度係数の分布をそのまま用いた場合 の座屈荷重の変化を、図中に破線で示した。ただし1次モードの座屈 荷重のみ示している。破線と実線の結果を比較すると、感度係数の 分布を用いたにも関わらずモードの絶対值の分布を用いた場合の方 が座屈荷重は大きくなっている。これは、構造材総体積が一定とな るようライズのスケーリングを行っている為、感度係数の分布が必 ずしも効率の良い形状修正とはならない為である。比較の対象とし て、ライズのスケーリングを行わずに単純に感度係数の分布を加え て形状修正を行った場合の結果を点線で同図中に示す。この場合、

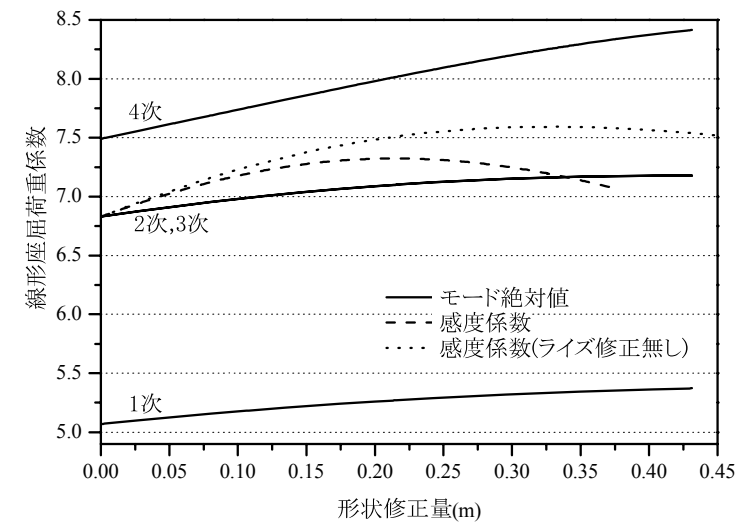

（a）線形座屈荷重係数と形状修正量の関係

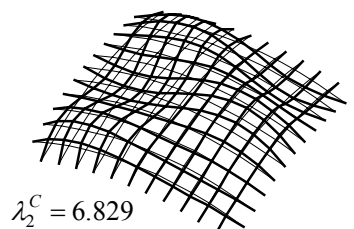

(b) 座屈モード

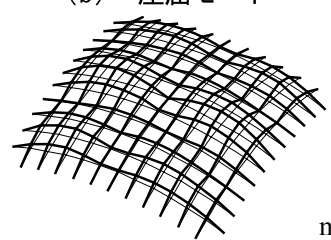

(d) 座屈モード絶対值 max

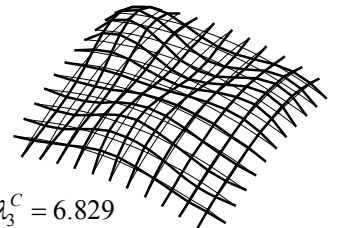

(c) 3次座屈モード 図

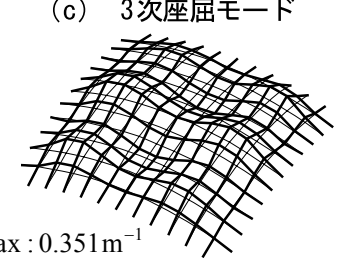

(e) 感度係数分布
図6 格子シェルAの2 次モードに対する形状修正
これまでの3つの結果のうちで最も座屈荷重が大きいことが確認でき る。実線の傾きは点線の傾きの8 割程度であり、提案手法は感度係数を 用いずに比較的効率良く座屈荷重を上昇させていることが分かる。

次に2次モードに対する形状修正を扱う。高次モードに対して形状 修正を行うことは実際の構造物では利点は少ないと考えるが、ここ では形状修正による座屈荷重の変化の傾向を確認することを目的と する。2次の座屈モード(図6(b))の絶対值の分布(図6(d))をそのまま形状 修正の分布として用いると、初期の構造形状が持つ対称性が崩れる 事になる。また2次モードと3次モード(図6(c))の座屈荷重は等しく、 $\mathrm{z}$ 軸周りに90度回転させると2次モードと3次モードは互いに同じモー ド形状をしている。前述の対称性の崩れる形状修正を行うと2次モー ドの座屈荷重は上昇するが、3次モードの座屈荷重は下降する傾向が あり、このような形状修正を行う利点は少ない。そこで、最適設計 で良く用いられる設計変数のグルーピング処理を施し、対称関係に ある節点は修正量が等しくなるように修正することとした。具体的 な計算方法を付録Aに示す。

この形状修正による線形座屈荷重の変化を図6(a)に示寸。形状修正 量 $0.43 \mathrm{~m}$ のとき、2次及び3次の座屈荷重係数は6.83から7.18へと $5 \%$ ほど 上昇した。また、1次モードの場合と同栐に、形状修正の分布に感度 係数を用いた場合と、感度係数を用いるがライズのスケーリングを 行わない場合の結果も同図中に記入した。これら感度係数を用いた 場合の結果は、形状修正量が大きくなるにつれて座屈荷重が一旦上 昇したのち下降している。これは座屈モードが高次の座屈モードと 連成して変化するのが原因であるが、この現象については後の解析 例で詳しく説明する。提案手法は刘称性を考慮した為に1次モードの 場合と比べると座屈荷重の改善効率は若干悪いが、感度係数を用い

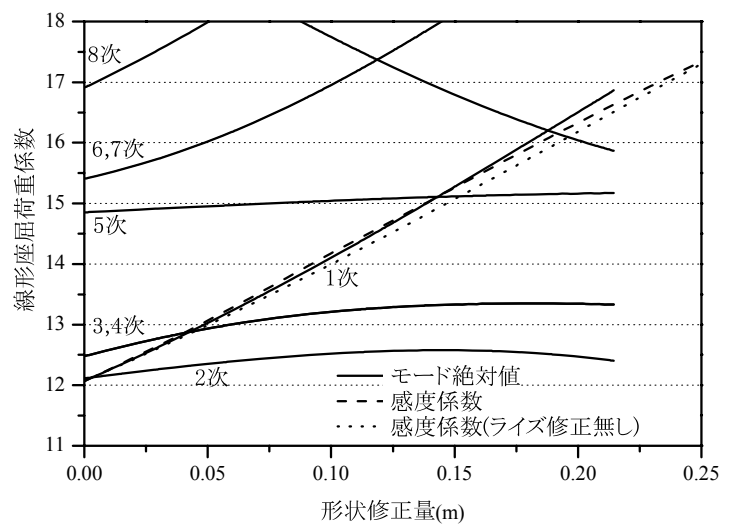

（a） 線形座屈荷重係数と形状修正量の関係

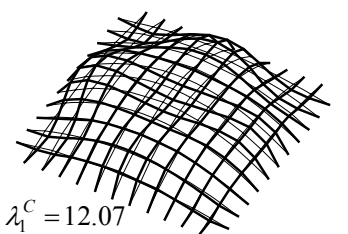

(b) 座屈モード

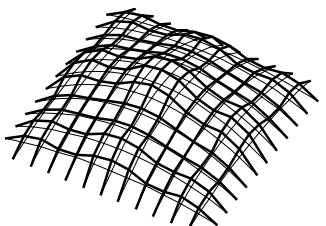

（c） 座屈モード絶対値

$$
\max : 0.638 \mathrm{~m}^{-1} \text { (d) 感度係数分布 }
$$

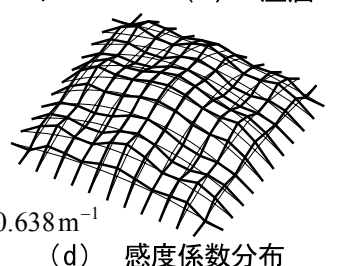

図7格子シェルBの1 次モードに対する形状修正 


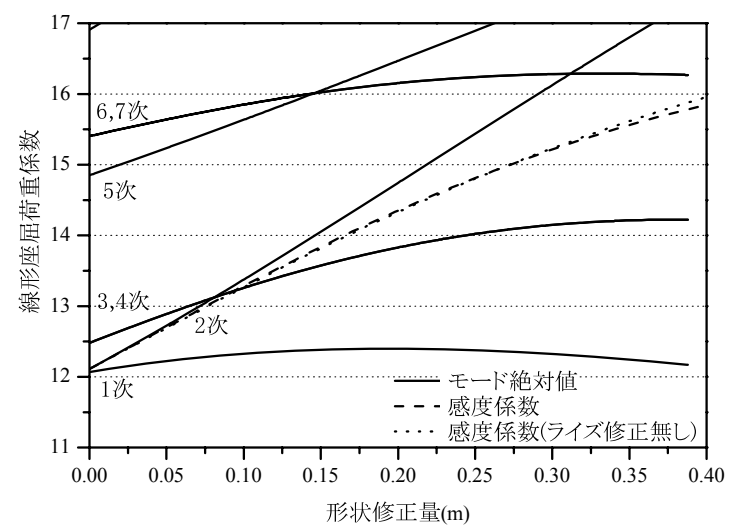

（a）線形座屈荷重係数と形状修正量の関係

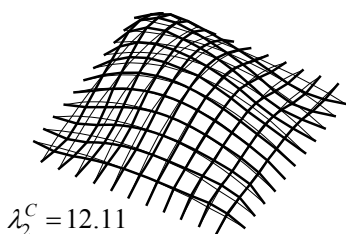

(b) 座屈モード

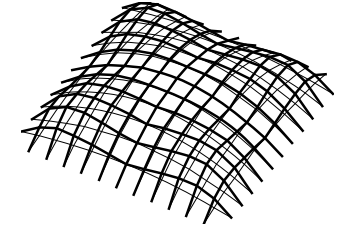

（c）座屈モード絶対値

$\max : 0.911 \mathrm{~m}^{-1}$

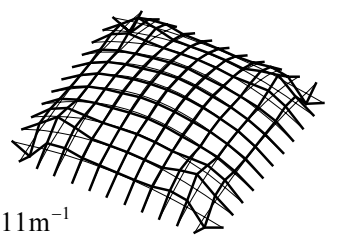

(d) 感度係数分布

図8格子シェルB の2 次モードに対する形状修正

ずに座屈荷重を上昇させることができている。

同様に格子シェルBのモデルに対して、1次モードの絶対值の分布 を用いて形状修正を与えた時の結果を図7に、2次モードの絶対值の 分布で形状修正を与えた時の結果を図8に示す。このモデルでは、1 次と 2 次の座屈荷重が近いためにすぐに最小座屈荷重の入れ替わりが 生じてしまうものの、形状修正に対応したモードの座屈荷重は上昇 していることが確認できる。座屈モードの絶対值の分布と感度係数 の分布も比較すると、2次モードの場合では感度係数は凸の部分が隅 角部付近に局所的に分布しており(図8(d))幾らか差が見られるが、巨 視的に見れば両形状は似ていると言えそうである。なお、2次モード に対する形状修正では感度係数を用いた場合の座屈荷重が、提案手 法の座屈荷重より小さくなっている（図8(a)）。感度係数に比例した 修正は修正ノルムを一定とする時に最も効率が良く、図8(a)の横軸の ように同一の最大修正量で比較すると必ずしも効率が良いとは限ら ない。特に図8(d)のように感度係数の分布が座屈モードに比べ局所的 となる場合では、最大修正量で比較すると座屈荷重の上昇率は小さ くなる。

\section{2 三方向グリッドドーム}

解析モデルを図 9 に示す。スパン $100 \mathrm{~m} 、$ ライズ $15 \mathrm{~m}$ の球形ドームで ある。曲面分割は投影平面上で等分割した三方向グリッドとし、母 線方向に 8 分割とした。外力は等分布荷重 $1.0 \mathrm{kN} / \mathrm{m}^{2}$ を与える。部材は $\phi 267.4 \times 6.0$ としヤング係数 $205 \mathrm{GPa}$ 、せん断弾性係数 $79 \mathrm{GPa}$ で解析を 行った。支持条件はピン支持とした。なお、本研究ではシェル型の 全体座屈の夕対象とする為、一部材を一要素でモデル化し、個材座 屈は考慮しない（前節の格子シェルでは全体座屈が常に先行する）。

これまでと同様に、座屈モードの絶対值の分布に比例した形状修
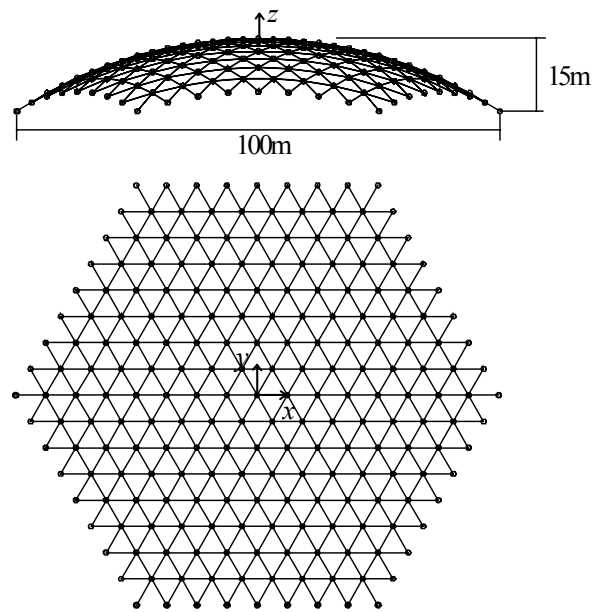

図9解析モデル（三方向グリッドドーム）

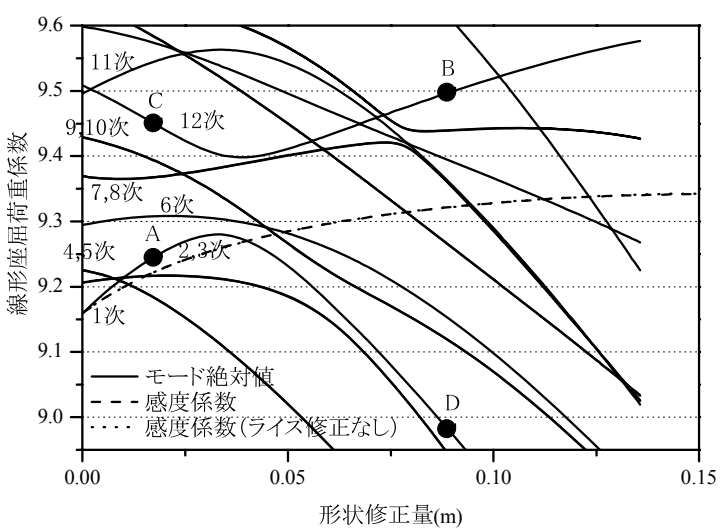

（a）線形座屈荷重係数と形状修正量の関係

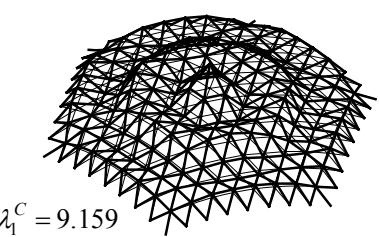

(b) 座屈モード

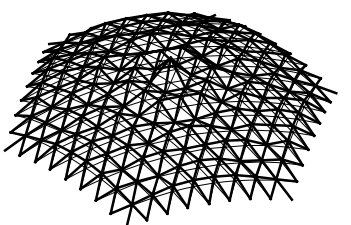

(c) 座屈モード絶対値

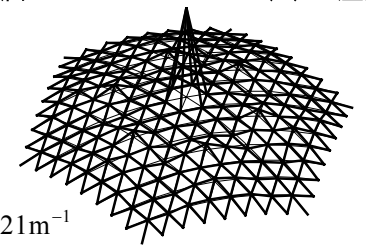

(d) 感度係数分布

図10 三方向グリッドドームの 1 次モードに対する形状修正

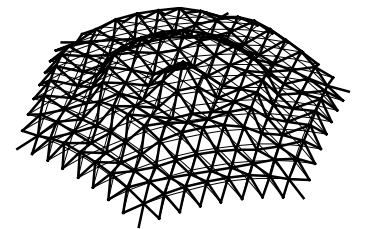

(a) A 点の座屈モード

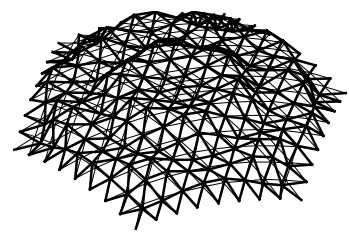

(c) C点の座屈モード

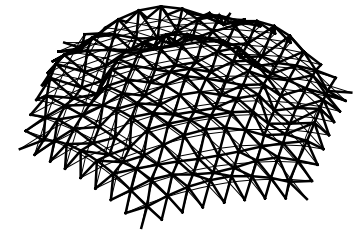

(b) B 点の座屈モード

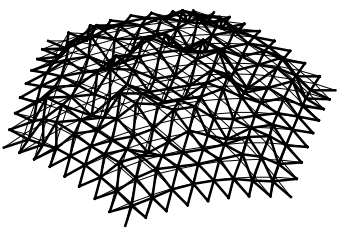

(d) D点の座屈モード
図11 モードの遷移 (1 次モード) 


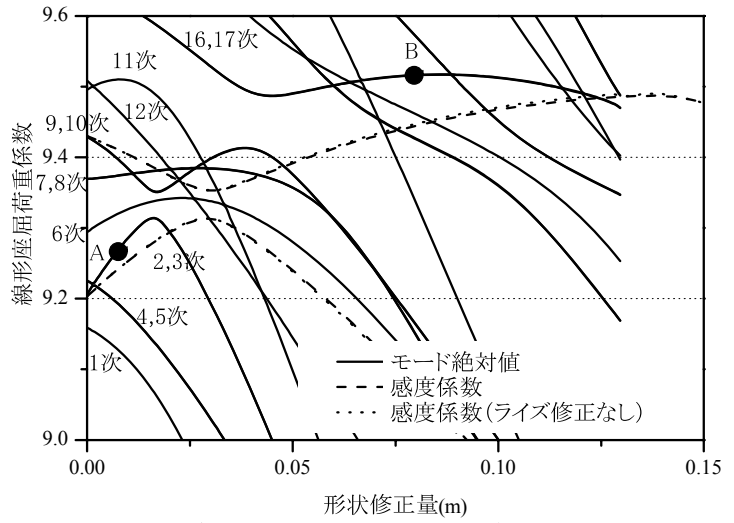

（a） 線形座屈荷重係数と形状修正量の関係

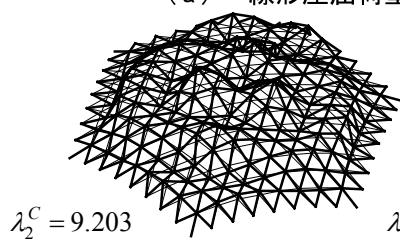

(b) 座屈モード

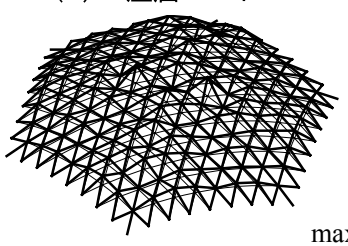

（d）座屈モード絶対值

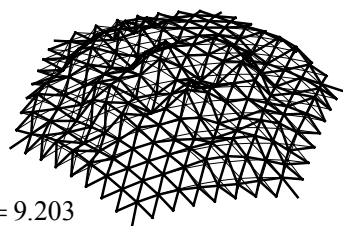

(c) 3 次座屈モード

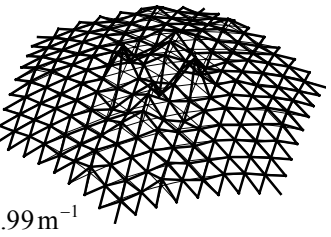

(e) 感度係数分布

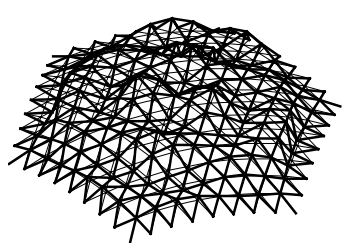

(a) A 点の座屈モード

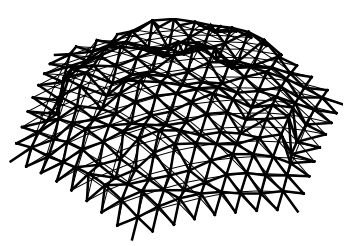

(b) B 点の座屈モード

図13 モードの遷移 (2 次モード)

正を与え、座屈荷重の変化を調査する。形状修正として加えるモー ド絶対值の最大振幅は $0 \mathrm{~m} \sim 0.2 \mathrm{~m}$ の範囲で変化させた。

1次座屈モード及び1次座屈モードの絶対值の分布を図10(b),(c)に、感 度係数の分布を図10(d)に示す。格子シェルの場合に比べ、座屈モー ドの絶対值の分布と感度係数の分布には一見大きな差があるように 見える。しかし詳細に見ると、感度係数の分布が凸の部分では座屈 モードの絶対值の分布も凸となる傾向を確認することができた。形 状修正を行った際の線形座屈荷重の変化を図10(a)に示寸。図を見る と1次モードの曲線は形状修正の振幅が $0.03 \mathrm{~m}$ 付近までは上昇し、それ 以降では下降していることがわかる。しかし、高次モードの変化を 見ると 12 次モードの座屈荷重の曲線が1次モードの曲線と反発しあう ような振る舞いを示している。これは1次モードと12次モードの間で (1)式の固有方程式が連成し、形状修正に伴ってモード形状が遷移す るためである ${ }^{8)}$ 。図10(a)中のA,B,C,D点における座屈モードを図11(a)〜 (d)に示す。A点の座屈モードは図10(b)の1次の座屈モードとほぼ同じで あるが、同じ曲線上にあるD点では座屈モードは大きく変化してお り、同じ曲線上にない $\mathrm{B}$ 点のモードの方が形状が近いことが分かる。 反対にC 点と $\mathrm{D}$ 点の座屈モードが互いに良く似ている。以上の考察か ら、形状修正前の1次モードに対応寸る座屈荷重は、調查した範囲にお

いて形状修正量が増加するにつれ上昇しつづけていることが分かる。 2次モードに対しても同様に形状修正を行った。2次と3次の座屈 モード(図12(b),(c))は対称性によって重複関係にあるモードであったた め、格子シェルAの場合と同様に節点のグルーピングを行い、対称性 を保持したまま形状修正を行う。2次モードの絶対值の分布を図12(d) に、感度係数の分布を図12(e)に示す。この場合も感度係数の分布が 凸の部分では座屈モードの絶対值の分布も凸となる傾向が確認でき た。形状修正による座屈荷重の変化を図12(a)に示す。2次モードの形 状修正では2,3次モード、9,10次モード、16,17次モードの間でモードの 遷移が生じている。図中A点、B点の座屈モードを図13に示す。

\section{3 自由曲面ラチスシェル}

解析モデルを図14に示す。曲面形状は次式で与えられる。

$$
z=\frac{1}{3}(y-300) \sin \left(\frac{\pi}{200} \sqrt{5 x^{2}+(y-300)^{2}}\right)-90 \quad \text { (unitm) }
$$

長辺スパン $132.59 \mathrm{~m}$ 、短辺スパン $60.18 \mathrm{~m}$ 、ライズ $12.16 \mathrm{~m}$ である。曲面分 割は投影平面上で等分割した一辺 $6.6 \mathrm{~m}$ の三方向グリッドとした。一 部材を一要素でモデル化し、個材座屈は考慮しない。外力は等分布 荷重 $1.0 \mathrm{kN} / \mathrm{m}^{2}$ 、部材は $\phi 318.5 \times 6.0$ 、ヤング係数 $205 \mathrm{GPa}$ 、せん断弾性係 数79GPaで解析を行った。支持条件は周辺ピン支持とした。

1次の座屈モード及び座屈モードの絶対值の分布を図15(b),(c)に、1次 座屈荷重係数の節点z座標に対する感度係数の分布を図 $15(\mathrm{~d})$ に示す。 これまで同様、座屈モードの絶対值の分布 (図15(c)) と感度係数の 分布 (図15(d)) は比較的良く似ていることが分かる。

提案の形状修正の方法により1次の座屈モードについて形状修正を 行い、座屈荷重の変化を調査した結果を図15(a)に示す。図中の横軸 は形状修正量（形状修正前後におけるz座標の差の最大值）である。 形状修正量 $1.81 \mathrm{~m}$ （図中C点）のとき線形座屈荷重係数は5.23から 7.63 へと $46 \%$ 上昇した。

これまでの解析はすべて座屈前非線形性を無視した線形座屈荷重 を扱っている。しかし、比較的偏平な単層ラチスシェルでは、座屈 前非線形性による影響が無視できない場合が多い。そこで非線形座 屈荷重（弾性座屈荷重）の值についても調査を行った。

図15(a)中のA，B，C点のモデルに対してそれぞれ幾何学的非線形解析 を行い非線形座屈荷重を求めた。結果を表 1 に示す。表中には線形座 屈荷重の值も同時に示してある。非線形座屈荷重はいずれのモデル も線形座屈荷重の8割程度であり、線形座屈荷重が上昇したのと同程 度に非線形座屈荷重も上昇していることが分かる。A,B,C点における それぞれのモデルの形状の比較を図16に示した。同図は、図14に示 したA-A’断面での比較である。

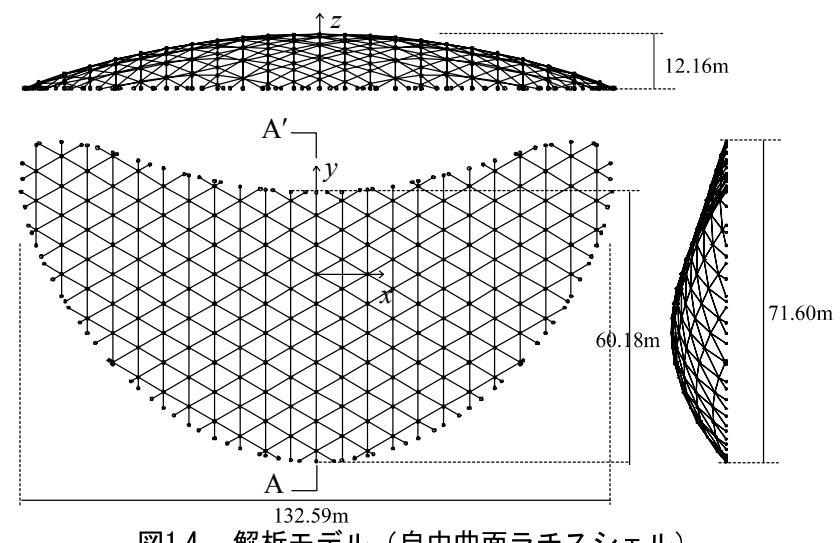

図14 解析モデル（自由曲面ラチスシェル） 


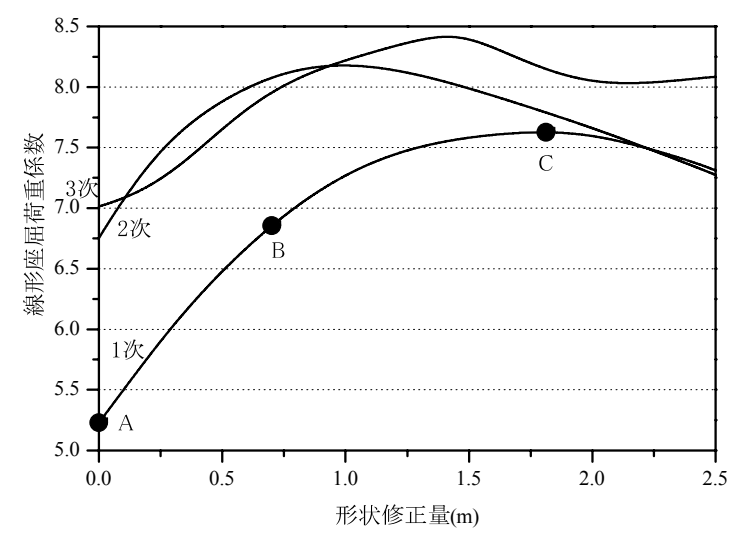

（a） 線形座屈荷重係数と形状修正量の関係

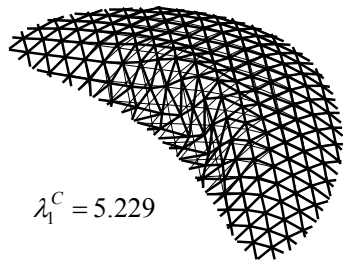

(b) 座屈モード

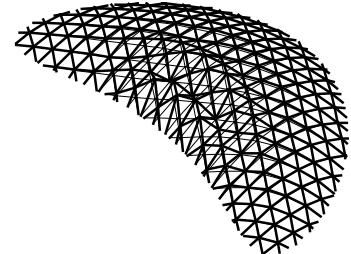

(c) 座屈モード絶対値

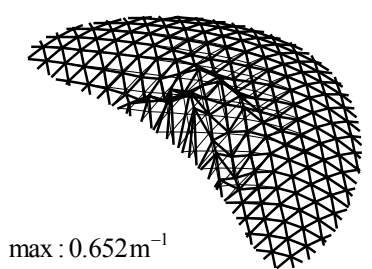

(d) 感度係数分布

図15 自由曲面ラチスシェルの1 次モードに対する形状修正

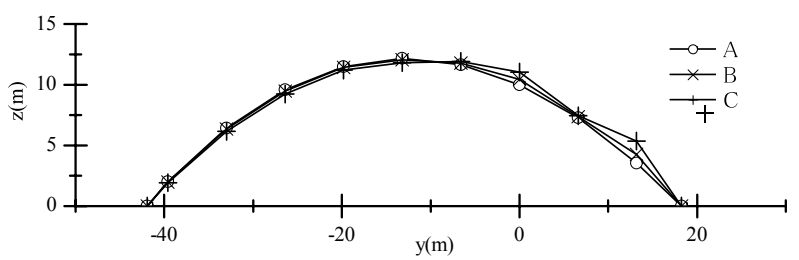

図16形状の比較 ( $A-A$ ' 断面)

表1 線形座屈荷重と非線形座屈荷重の比較

\begin{tabular}{|c|l|l|c|}
\hline & $\begin{array}{c}\text { 線形座屈 } \\
\text { 荷重係数 }\end{array}$ & $\begin{array}{c}\text { 非線形座屈 } \\
\text { 荷重係数 }\end{array}$ & $\begin{array}{c}\text { 比率 } \\
\text { (非線形/線形) }\end{array}$ \\
\hline $\mathrm{A}$ & 5.229 & 4.365 & 0.835 \\
\hline $\mathrm{B}(\mathrm{B} / \mathrm{A})$ & $6.854(1.311)$ & $5.288(1.211)$ & 0.772 \\
\hline $\mathrm{C}(\mathrm{C} / \mathrm{A})$ & $7.626(1.458)$ & $6.483(1.485)$ & 0.850 \\
\hline
\end{tabular}

\section{5. まとめ}

本研究は、単層ラチスシェルの線形座屈解析と感度解析を行い、 感度係数の分布の傾向を調査した。そして、その傾向から、座屈 モードのみから簡単に座屈荷重を上昇させるような形状修正の分布を 生成する方法を提案した。以下に本報で得られた結果をまとめる。

1)本論で扱った格子シェルA,B、三方向グリッドドーム、自由曲面ラ チスシェルはいずれも座屈モードの絶対值の分布と節点z座標に関 する座屈荷重の感度係数の分布が比較的良く似ていた。シェル型 の座屈を生じるラチスシェルでは、他の形状でも同様の傾向があ るものと考えている。

2)上記1)の傾向を利用し、座屈モードの絶対值の分布を形状に足し合

わせることによってそのモードに対応する座屈荷重を上昇させる ことができる。

3)提案手法を1次モードの座屈荷重が相対的に小さい自由曲面ラチス シェルに適用し、座屈性状の改善を試みた（4.3節）。その結果、 線形座屈、非線形座屈ともに初期值から 1.5 倍程度に上昇させるこ とができた。

ここで示した例題以外にも幾つかのモデルについて調査し、座屈 荷重が上昇することを確認している。必ずしも解析例は十分とは言 えないため、今後も解析例を増やし同様の傾向があるのか確認する 必要があるが、本手法によって他の構造モデルに対しても線形座屈 荷重を上昇させることができるものと考える。

なお、本論は簡単に言えば、座屈モードの腹の部分をシェルの外 側に膨らませることで座屈荷重が上昇する傾向にあることを示すも のである。形状修正の分布を機械的に作成するために座屈モードの 絶対値の分布を利用したが、曲面の傾きが不連続となる部分では曲 げ応力を生じやすいので、適宜スムージングするなどした方が良い であろう。

本手法は線形座屈荷重を上昇させる為の形状修正方法である。弾 性座屈する構造モデルや、弾塑性座屈するが材料非線形性の影響の 比較的小さい構造モデルに本手法を適用すると座屈耐力を上昇させ ることが期待できる。一方で、材料非線形性の影響を大きく受ける モデルでは本手法で座屈耐力を上昇させることは難しいものと考え る。また、対象とする座屈はシェル型の全体座屈であり、個材座屈 は考えていない。

曲げ変形の小さい形状ほど座屈荷重が大きいと考える技術者は多 い。その為、曲げ変形を打ち消寸ようにたわみ分布を反転させて形状 修正に与えた場合の線形座屈荷重の変化について付録Bに示した。ま た、論文中の解析モデルは全て境界条件を単純なピン支持とした。そ の他の境界条件とした場合の例題について付録Cに示した。本論で は修正前後の形状に対して初期不整敏感性は特に調査しなかった。座 屈に対して最適化を行うと不整に敏感となる場合があることが指摘さ れており17)、不整敏感性の変化は重要な検討項目であるが、これにつ いては今後の課題としたい。

\section{謝辞}

本研究を進めるにあたり、平成 25 年度東海大学卒論生高橋啓太 朗氏に多くの協力を得ました。ここに記して謝意を表します。

\section{参考文献}

1)R. H. Plaut, and N. Olhoff, Optimal Forms of Shallow Arches with Respect to Vibration and Stablility, J. Struct. Mech., 11(1), pp.81-100, 1983

2)R. H. Plaut, and L. W. Johnson, Optimal Forms of Shallow Shells with Circular Boundary, J. Appl. Mech., Vol.51, pp. 527-539, 1984

3)R. Reitinger, and E. Ramm, Buckling and imperfection sensitivity in the optimization of shell structures, Thin-Walled Structures, 23, pp.159-177, 1995

4) 陳沛山, 川口衛 : スペース・フレームの最大座屈荷重形態, 日本建築学 会構造系論文集, No.489,pp.41-46, 1996.11

5) 小河利行，大崎純、立石理恵：線形座屈荷重最大化と部材長一様化を目 的とした単層ラチスシェルの形状最適化、日本建築学会構造系論文集, No.570, pp.129-136, 2003.8

6)山本憲司, 皆川洋一, 大森博司：座屈荷重を目的関数と寸る空間構造の 形状最適化に関寸る研究，日本建築学会構造系論文集，No.564，pp.95102, 2003.2 
7)F. Trentadue, Minimum weight design of non-linear elastic structures with multimodal buckling constraints, Int. J. Numer. Meth. Engng, Vol.56, pp.433-446, 2003

8)山本憲司, 皆川洋一, 大森博司：剛性行列のブロック対角化を利用した 線形座屈荷重を目的関数とする単層卜ラスドームの形状最適化，日本建 築学会構造系論文集, No.578, pp. 51-58, 2004.4

9)熊川恵理子，佐々木睦朗：木造ラチスシェルに関する研究：弾性座屈荷重 最大化による形態創生, 日本建築学会大会学術講演梗概集, B-1, pp.729$730,2011.7$

10)林裕真, 竹内徹, 小河利行 : 地震荷重下の座屈耐力に着目した単層格子屋 根構造の形状探索, 構造工学論文集, Vol. 59B, pp. 479-488, 2013.3

11)木村 俊明, 大森 博司: 線形座屈荷重を目的関数とした形状最適化法の構 築, 構造安定性を考慮した自由曲面シェル構造の構造形態創生手法の提 案その1, 日本建築学会構造系論文集, No. 686, pp.733-741, 2013.6

12)小林晃子, 重田幸乃, 熊谷知彦, 小河利行 : 矩形平面単層ラチスシェル の形状および部材剛性分布の最適化, 日本建築学会大会学術講演梗概 集, B-1, pp.963-966, 2013

13 ) 能井宏弥, 藤井大地: 力法の原理を用いたシェル構造の形状最適化, 日 本建築学会構造系論文集, No.616, pp.121-126, 2007.6

14)萩原伸幸：曲げモーメント分布に従う形状修正による軸力抵抗型構造の 形成, 日本建築学会大会学術講演梗概集, B-1, pp.395-396, 2010 15)山田聖志：座屈前に幾何学的非線形性を有するシェル構造物へのRS法の 適用，日本建築学会構造系論文報告集，No.390, pp.88-97, 1988.8 16)加藤史郎，原亮，中澤祥二：4 点支持鉄筋コンクリートドーム屋根の耐 力に関する解析的分析, 日本建築学会構造系論文集, No.669, pp.1935pp.1942, 2011.11

17)J. M. T. Thompson, and G. W. Hunt, A General Theory of Elastic Stability, John Wiley, New York, 1973

\section{付録A 対称性を考慮した形状修正}

最適設計で良く用いられるような設計変数のグルーピング処理を施し、対称 関係にある節点の座標を修正量が等しくなるよう修正することを試みる。

本文の格子シェルのモデルでは刘称関係にある節点は8個の節点から成る（一 例を図A.1に示す)。これらの節点がそれぞれ独立に $\Delta z_{1}, \Delta z_{2}, \cdots, \Delta z_{8}$ だけ修 正する事により見込める座屈荷重係数の上昇值 $\Delta \lambda_{i}^{C}$ は、感度係数を用いて 表すと次式になる。

$$
\Delta \lambda_{i}^{C}=\frac{\partial \lambda_{i}^{C}}{\partial z_{1}} \Delta z_{1}+\frac{\partial \lambda_{i}^{C}}{\partial z_{2}} \Delta z_{2}+\cdots+\frac{\partial \lambda_{i}^{C}}{\partial z_{8}} \Delta z_{8}
$$

ここで、 $\Delta z=\Delta z_{1}=\Delta z_{2}=\cdots=\Delta z_{8}$ であるとすれば、

$$
\begin{aligned}
\Delta \lambda_{i}^{C} & =\frac{\partial \lambda_{i}^{C}}{\partial z_{1}} \Delta z_{1}+\frac{\partial \lambda_{i}^{C}}{\partial z_{2}} \Delta z_{2}+\cdots+\frac{\partial \lambda_{i}^{C}}{\partial z_{8}} \Delta z_{8} \\
& =\left(\frac{\partial \lambda_{i}^{C}}{\partial z_{1}}+\frac{\partial \lambda_{i}^{C}}{\partial z_{2}}+\cdots+\frac{\partial \lambda_{i}^{C}}{\partial z_{8}}\right) \Delta z \\
& =\left(\frac{1}{8} \sum_{i=1}^{8} \frac{\partial \lambda_{i}^{C}}{\partial z_{i}}\right) \Delta z+\left(\frac{1}{8} \sum_{i=1}^{8} \frac{\partial \lambda_{i}^{C}}{\partial z_{i}}\right) \Delta z+\cdots+\left(\frac{1}{8} \sum_{i=1}^{8} \frac{\partial \lambda_{i}^{C}}{\partial z_{i}}\right) \Delta z
\end{aligned}
$$

すなわち、対称関係にある節点を常に同じだけ修正する場合、対称関係にあ る節点の感度係数の平均をとり、これを各節点の感度係数に置き換えても同 じ結果が得られる。以上の考察から、座屈モードの絶対值の分布を対称関係

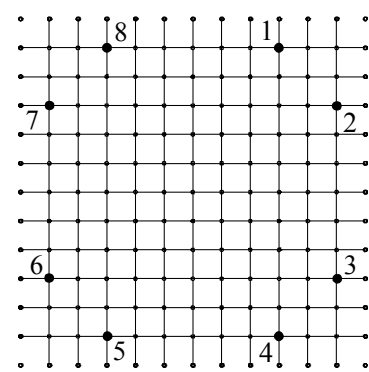

図A. 1 対称関係にある節点の例

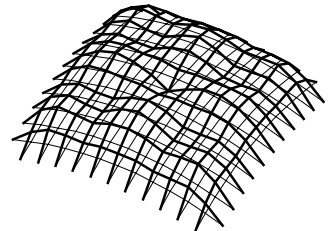

図A. 2 対称性を考慮した形状修正モード

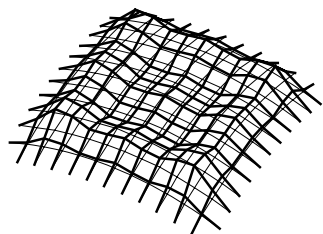

図A. 3 対称性を考慮した感度係数の分布
にある節点グループ毎に平均し、構造形状と同じ対称性をもつ形状修正モ一 ドを作成した。本文の格子シェルAの2次モードの絶対值（図6(d)）に対し て、対称性を考慮した場合の形状修正モードを図A.2に示す。また、比較の 為、格子シェルAの2次の座屈荷重の感度係数の分布を、同様に対称性を考慮 した場合の分布を図A.3に示す。前者は後者に比べ中央の凹みが小さいが、巨 視的に見れば凹凸の対応関係が幾らか認められる。

\section{付録B たわみ分布に比例した形状修正}

たわみ分布に比例した形状修正を行った場合の線形座屈荷重の変化を調 查する。解析モデルは4,1節と4.2節で示した格子シェルA,Bと3方向グリット シェルとする。等分布荷重により生ずるたわみ（z方向変位）を反転させ、任 意の係数倍して節点座標に加える。その後、3章で述べたのと同様に構造材の総 体積が形状修正前と同一となるよう高さ方向に節点座標のスケーリングを行う。

格子シェルAの結果を図B.1(a)に示す。横軸は形状修正量、縦軸は1次モード の線形座屈荷重係数を表している。一点鎖線はたわみ分布による形状修正の 結果を表しており、実線および点線は本文で示したモードの絶対值および感 度係数による形状修正の結果を表している。また、図B.1(b)はたわみ分布を示 しており、-500倍して表している。同様に格子シェルBの1次モードの結果を 図B.2に、3方向グリッドドームの1次モードの結果を戝B.3にそれぞれ示す。

たわみ分布による形状修正を行った場合、格子シェルBでは他の2つの方法 に比べ線形座屈荷重の上昇が小さく、3方向グリッドドームでは線形座屈荷 重は低下している。たわみ分布に比例した形状修正を与えることによって外 力に対する剛性が上昇し、座屈前非線形性が小さくなることで弾性座屈荷重 が上昇する効果は幾らかあるものと考える。しかし、これらの結果から線形 座屈荷重が上昇寸る（弾性座屈の巨視的な性状を改善する）とは限らないこ とがわかる。
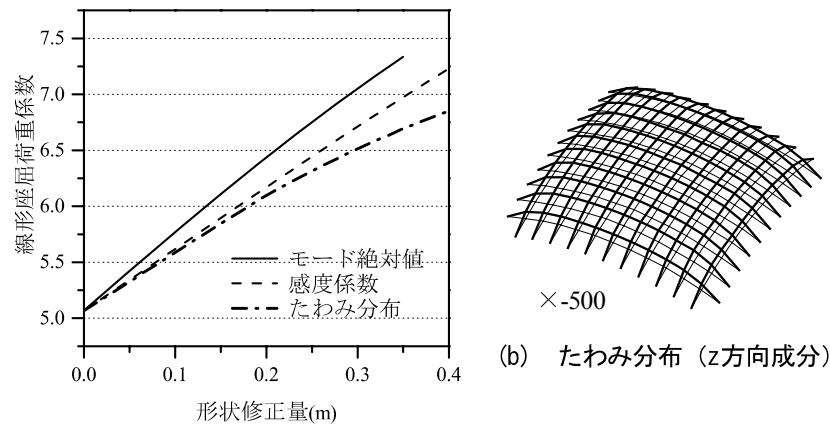

（b）たわみ分布（z方向成分）

（a） 線形座屈荷重係数と形状修正量の関係

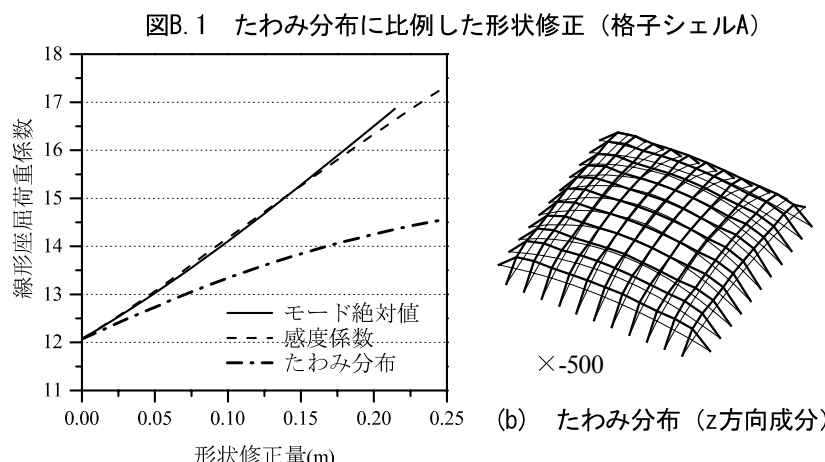

（a） 線形座屈荷重係数と形状修正量の関係

図B. 2 たわみ分布に比例した形状修正（格子シェルB）
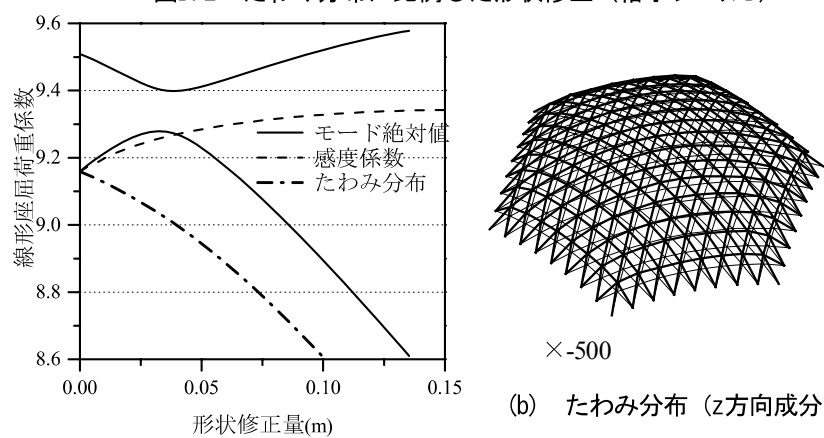

（b）たわみ分布（z方向成分）
線形座屈荷重係数と形状修正量の関係

図B.3 たわみ分布に比例した形状修正（3方向グリッドドーム） 


\section{付録C 境界条件の影響}

本文ではシェルの境界条件を理想的なピン支持とした。ここでは境界に岡 性の大きな部材を配置してローラー支持とした場合について線形座屈荷重の 感度解析を行い、感度係数の分布を調査する。

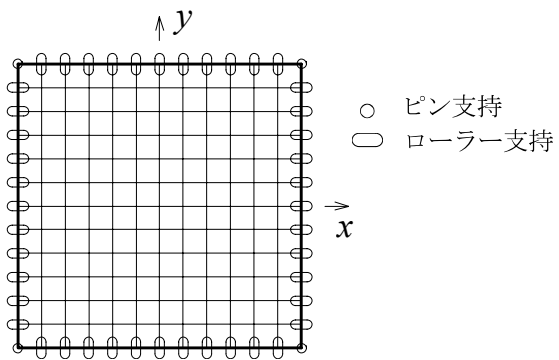

図C. 1 境界条件（格子シェルA, B）
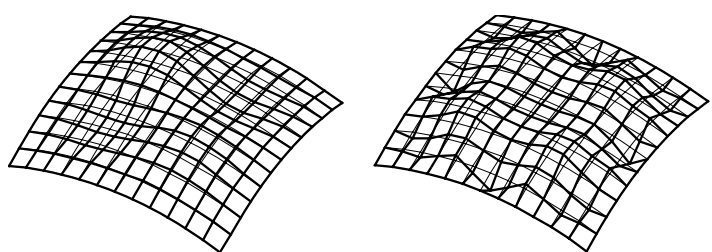

$\lambda_{1}^{C}=9.276$

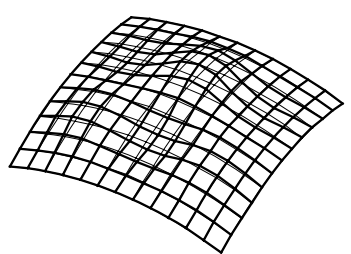

$\max : 0.500 \mathrm{~m}^{-1}$

$\lambda_{2}^{C}=11.50$
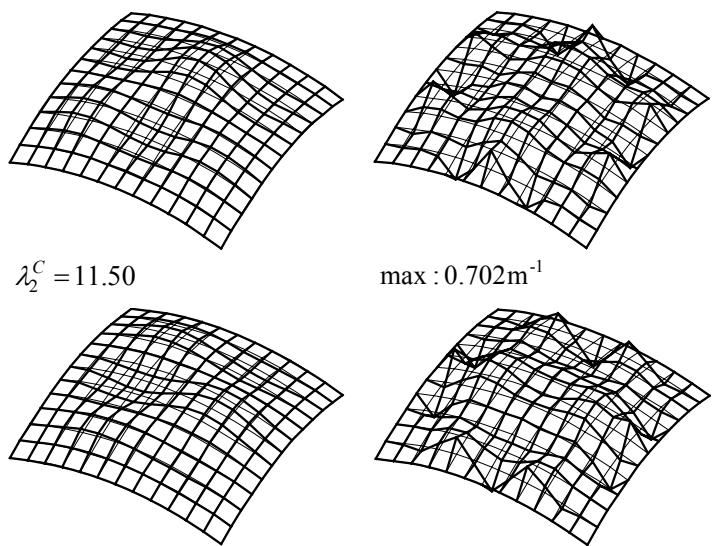

$\max : 0.702 \mathrm{~m}^{-1}$

$\lambda_{3}^{C}=11.50$

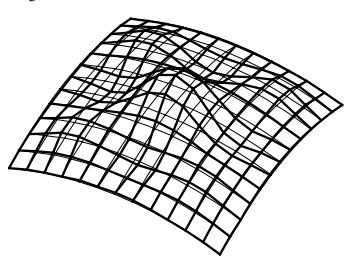

$\lambda_{4}^{C}=13.19$

(a) 座屈モード

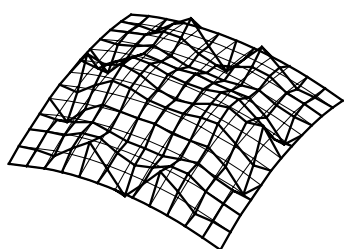

$\max : 0.702 \mathrm{~m}^{-1}$

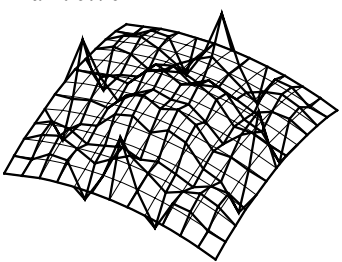

$\max : 1.28 \mathrm{~m}^{-1}$

(b) 感度係数分布

図C. 2 格子シェルAの感度解析結果

解析モデルは本文4.1節と同じ格子シェルA,Bの二つのモデルとする。新た に境界に追加寸る部材（図C.1の太線の部材）の直径、管厚をともに格子材の 4倍の寸法と仮定した。支持条件は図C-1に示すように隅角部の4点をピン支持 とし、それ以外の境界節点をローラー支持とした。

格子シェルAにおける座屈モードおよび感度係数の分布を図C-2に、格子 シェルBにおける結果を図C-3に示す。格子シェルAでは感度係数が境界付近 で大きく波打っており、座屈モードの絶対值の分布と感度係数の分布は必ず しもよく似た分布とはならない。この境界条件では、境界付近の節点座標が 座屈荷重に大きな影響を与えるようである。しかし、感度係数分布を巨視的 に見ると座屈モードの腹の部分はやはり上に凸となる傾向は確認できる。こ のため、提案手法による形状修正を行った場合もやはり座屈荷重の上昇は期 待できる（実際に提案手法によって線形座屈荷重が上昇することを確認して いる）。一方、格子シェルBの場合では同じローラー支持でも境界付近で大き な感度は生じなかった。感度係数分布はピン支持の場合と同様の傾向を示し ている。

境界条件の違いが感度係数の分布に与える影響は、モデルによって差がある ようであるが傾向を把握するまでには至っておらず、今後詳細に検討する必要 がある。
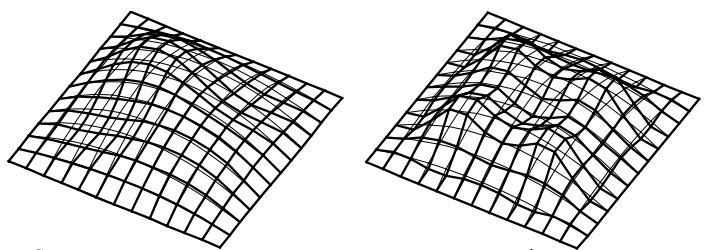

$\lambda_{1}^{C}=17.42$

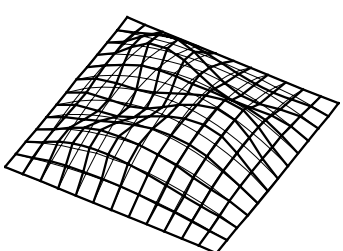

$\max : 0.969 \mathrm{~m}^{-1}$

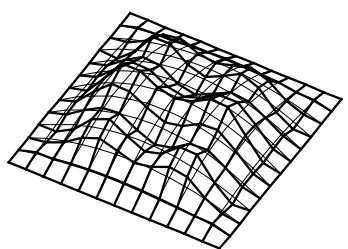

$\lambda_{1}^{C}=18.67$

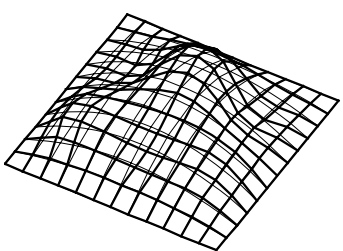

$\lambda_{1}^{C}=18.67$

$\max : 0.906 \mathrm{~m}^{-1}$

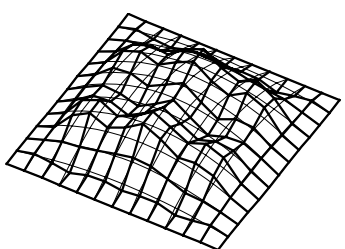

$\max : 0.906 \mathrm{~m}^{-1}$

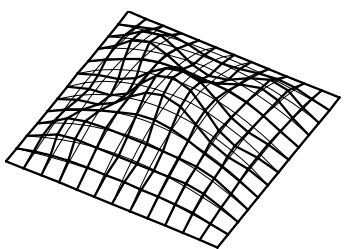

$\lambda_{1}^{C}=20.03$

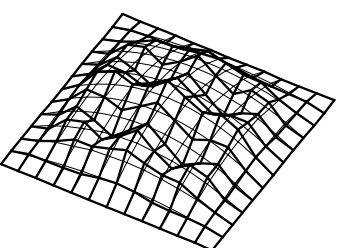

$\max : 0.966 \mathrm{~m}^{-1}$
（a）座屈モード
(b) 感度係数分布

図C. 3 格子シェルBの感度解析結果 


\title{
SHAPE MODIFICATION OF SINGLE-LAYER RETICULATED SHELLS FOR INCREASING LINEAR BUCKLING LOAD
}

\author{
Kenji YAMAMOTO* \\ * Assoc. Prof., Dept. of Architecture, Tokai Univ., Dr. Eng.
}

\section{Introduction}

This paper examined a technique of shape modification for increasing linear buckling load of single-layer reticulated shells. The sensitivity analysis of the linear buckling load of a single-layer reticulated shell with respect to the nodal coordinates is performed, and the distributions of the sensitivity coefficients are examined in detail. The tendency of the distributions is utilized, and the technique of shape modification to increase a buckling load using only linear buckling mode is proposed.

\section{Sensitivity Analysis}

\subsection{Sensitivity Analysis Method}

The sensitivity coefficient of a linear buckling load factor can be calculated by the equation (3).

\subsection{Numerical Example of Sensitivity Analysis}

The sensitivity analysis of the linear buckling load of the two-way grid shell shown in Fig. 1 is performed. The cross section of members is $\phi 267.4 \times 6.0$, and the Young's modulus is $206 \mathrm{GPa}$. The uniformly distributed load of $1 \mathrm{kN} / \mathrm{m}^{2}$ is applied at each of nodes. The linear buckling modes from 1st to 4th are shown in Fig.2-a. The distributions of the sensitivity coefficients of the buckling load factor with respect to z coordinates of each node are shown in Fig. 2-b. And, the distributions of the absolute values of $z$ direction component of the buckling mode are shown in Fig.2-c. It is found that each distribution of Fig.2-c resembles the distribution of the sensitivity coefficients (Fig.2-b).

\section{Shape Modification for Increasing Linear Buckling Load}

Distribution of sensitivity coefficients indicates a direction that improves the function efficiently, and the method of giving modification proportional to the distribution is called the steepest descent method. Therefore, it is anticipated to increase the buckling load by adding distribution of the absolute value of the buckling mode, which resembles the distribution of the sensitivity coefficients, to the nodal coordinates of a reticulated shell. However, since the reason that the buckling load is increased might only be increase of the rise, the rise is adjusted so that the volume of structural members is the same before and after shape modification (see Fig.4).

\section{Numerical Examples of Shape Modification}

\subsection{Two-Way Grid Shells}

The grid shell shown in Chapter 2 is analyzed. The shape modification to the 1 st buckling mode is performed using the proposed technique, and the variations of the buckling loads are shown in Fig. 5-a. The axis of abscissa in the figure indicates the amount of shape modification, the maximum of the difference of $\mathrm{z}$ coordinates before and after modification. The curves in the figure show the variations of the buckling loads from the 1 st to the 4 th. The 1 st buckling mode is shown in Fig. 5-b, and the distribution of the absolute value of the 1st buckling mode is shown in Fig. 5-c. The distribution of the sensitivity coefficients of the 1st buckling load is shown in Fig. 5-d.

When the amount of shape modification is $0.35 \mathrm{~m}$, the 1 st buckling-load factor is 7.33 , and increased about 50 percent from 5.07 . It is found that giving the shape modification proportional to the distribution of the absolute value of buckling mode increases the buckling load. The result by the shape modification to the 2 nd mode is similarly shown in Fig. 6 .

\subsection{Free-Form Reticulated Shell}

The model for analysis is a free-form reticulated shell shown in Fig. 14. The curved surface of the shell is given by the equation (6). The cross section of members is $\phi 318.5 \times 6.0$. The result by the shape modification to the 1 st mode is shown in Fig. 15 .

\section{Conclution}

This paper proposed a technique of shape modification for increasing linear buckling load of single-layer reticulated shells, and the efficiency was confirmed. 